\title{
Bank Selection and Patronage By University Students: A Survey of Students in Umudike, Nigeria
}

\author{
Gazie S. Okpara ${ }^{1}$, Onuoha A. Onuoha ${ }^{2}$
}

${ }^{1}$ Associate Professor, Department of Marketing, Abia State University, Uturu, NIGERIA

${ }^{2}$ Lecturer, Department of Marketing, University of Port Harcourt, Port Harcourt, NIGERIA

\begin{abstract}
University students represent an attractive segment of customers for retail banks in many countries including Nigeria. The objective of this study is to find out the determinants of the choice of commercial banks by university students, using Michael Okpara University of Agriculture, Umudike (MOUAU). MOUAU is selected due to the plurality of its student mix, being the only federal university in Abia State. Data were collected through self-administered questionnaire to 250 final year students, across the university's ten colleges. Convenience sampling was used. Apart from the traditional analytical tools such as tables and percentages, data were also analysed using descriptive statistics and principal component analysis. The Cronbach's alpha was used to test the reliability of the measuring instrument. The results show that service is the most influential of all the six determinant-factors for the choice of commercial banks. Proximity, attractiveness, referrals, marketing and price followed suit, based on their mean scores. Recommendations were proffered for competitive bank management, focused on different market segments among university students.
\end{abstract}

Keywords: Student Banking, Umudike, University, ATM, Theory of Constraints

\section{INTRODUCTION}

C ommercial banks are established to provide financial services at a profit. The intense competition that exists in the market for financial services, presents a big challenge to the profitability of retail banking institutions of all sizes (Mokhlis, 2009). The competition and saturation in the banking industry requires banks to be more customer-focused. Customers are exposed to diverse choices and are much concerned about the value for their money. The implication is that there are limitless switching choices available, given the competitiveness in the Nigerian banking industry. Banks therefore, need to identify factors that influence a customer's choice of a commercial bank, and work towards them, better than competitors. Currently, there are about 22 licensed reconsolidated commercial banks jostling for customership in virtually all the 36 states in Nigeria (Businessday, 2012). The existence of different commercial banks in the country has made the banking sector highly competitive. Thus, to win the markets, banks should focus more on customer expectations.

Customers' bank selection dynamics had been given considerable attention by researchers (Sharma and Rao, 2010). Exploring such information will help banks to identify the appropriate marketing strategies that are needed to attract new customers and retain existing ones (Cleopas and Olawale, 2011). Sharma and Rao (2010) pointed out that one promising segment, which has not however, been given enough attention, is the younger, age-group university students. These students are usually first-time account holders, who, if nurtured properly, could evolve into prospective profitable retail or corporate clientele (Hinson,
Dasah and Owusu-Frimpong, 2009). Therefore, the analysis of this segment's choice dynamics is important in order to understand how these individuals select and prefer their banks.

Financial institutions wanting to create a lucrative customer base, need to start by establishing and developing long-term trust and relationship with the customers. This was expounded by Okeke (2008), who opined that the relationship between the bank and its customers goes beyond that between a buyer and a seller of service, to involve a bond based on trust and confidence. Mokhlis, Mat and Salleh (2008) argue that despite the fact that the majority of undergraduate students are unemployed and that their earnings come mainly from parental support and educational loans, they provide an excellent business opportunity for commercial banks. This is because these students, on graduation and subsequent employment, become veritable personal or business customers with improved financial standing (Iruka and Igwe, 2010). Moreover, most students, according to Cleopas and Olawale (2011), are likely to need a bank account to negotiate their educational scholarships, loans or parental contributions, and therefore being obliged to administer their own personal financial affairs. According to Kaynak and Harcar (2005), the traditional belief that only businesses and wage-earning customers bring major income to the bank is now being challenged. Students generally need banks to handle their transactions. University students not surprisingly, represent a critically important target market for banking services. The ability to value, understand and address the specific needs of this segment is now a trend- 
ing market reality. Existing literature shows that the student market is expanding (Mokhlis et al, 2008).

Nigeria is organized into 36 states, plus a federal capital territory (FCT) in Abuja. As a result of management gap created by departed colonial masters, and buoyed by the oil boom years of the 1970s, tertiary education was expanded to reach every sub-region. The federal and state governments were previously the sole authorities licensed to operate universities in Nigeria. Recently, however, licenses have also been granted individuals, corporate and religious bodies to establish private universities. The $\mathrm{Na}$ tional University Commission (NUC) is the major accreditation body that enforces uniform standard and sets admissions capacity of every university. Consequently, there are 123 universities in Nigeria, as at February 2012 (NUC Portal, 2013). This figure is made up of 36, 37 and 50 universities owned by the federal government, the state governments, and entities (individuals, corporate and religious bodies) respectively. Students' enrolment in these institutions is increasing year by year, as there are higher demands for university education in the country. The number of enrolment will continue to increase in the near future as there are plans to establish even more universities especially by the federal government, private individuals and religious organizations. Therefore, students are important in the long term viability and survival of commercial banks in Nigeria.

Hinson, et al (2009) suggest that in a global climate characterized by financial apprehension after the shock of the global financial melt-down, banks would have to pay the most critical attention to their varied customer audiences in order to rebuild trust and foster new customer loyalty bonds. With growing competitiveness in the banking industry and similarity of services offered by banks, it has become increasingly important that banks identify the factors that determine the basis upon which studentcustomers choose their providers of financial services.

\subsection{Statement of Problem}

Generally, the major bases for segmenting consumer markets include geographic, demographic, geo-demographic, and psychographic options (Okpara, 2002). Segmentation of customer markets offers commercial banks a discriminating method of grouping commercial bank customers in desired and profitable categories, so that their needs and wants may be effectively addressed through purposedriven marketing strategies. Previous studies on the criteria which young customers use to select commercial banks (Ta and Har, 2000; Lee and Marlowe, 2003; and Arasli, Katircioglu and Smadi, 2005) have focused on developed countries such as Poland, Singapore, United States, and Cyprus. Almossawi (2001) pointed out that although studies done in developed counties have contributed significantly to the literature on bank selection, their findings may not have universal applicability, due to differences in

Copyright $(C 2013$, Asian Business Consortium | ABR cultural, economic, and legal environments. A few studies such as Almossawi (2001) and Mokhlis et al. (2008) have focused on commercial bank selection in developing countries. No known study has investigated the choice dynamics among banks, by university students in Nigeria. This study seeks to fill this gap.

\subsection{Objectives of the Study}

One promising segment which has not been given adequate attention in bank patronage by researchers is students (Sharma and Rao, 2010). This is largely because they are unsalaried, young and financially inexperienced. The main objectives of the study are:

i. to examine the determinants of commercial bank preference by university students in Umudike, Nigeria.

ii. to rank these determining factors in their order of students' priority.

iii. to make recommendations on better student banking by Nigerian commercial banks.

\section{Literature ReVIEW}

\subsection{Theoretical Construct}

The theory of constraints (TOC) is a versatile systems methodology that has been developed to assist people and firms think about their problems, develop breakthrough solutions and implement those solutions successfully. Developed by Eliyahu Goldratt in 1990 (Mabin and Balderstone, 2003), the constraints begin when the firm loses its customers to its competitors or needs to attract more customers to sustain profitability. Firms use the TOC to assess the causes of customer loss, or factors that cause customer gain and loyalty (attraction and retention of customers). Customers choose alternative financial services providers, because of quality constraints, speed of service and staff courtesy among others (Cleopas and Olawale, 2012). Customers expect higher product and service quality than the price they are willing to pay to acquire those products and services (Mabin and Balderstone, 2003). The theory of constraints is applicable to commercial banks as are constrained by competitive pressures in a rapidly changing environment. They therefore, need to attract and retain customers to survive and grow. Understanding the determinants of commercial bank selection by customers is one way to reduce or eliminate these constraints to achieving bank wealth maximization (Bramorski, Madan and Motwan, 2002).

\subsection{Summary of Related Studies}

According to Almossawi (2001) there are many factors that can influence the choice of commercial banks by customers. One of the factors is feeling of security. Mokhlis (2009) points out that security reflects the desire to bank with a stable bank and assurance of confidentiality when making a financial transaction. This desire includes both security at the bank and the security of the bank. Gerrard 
and Cunningham (2001) conducted a study in Singapore that addressed the issue of how undergraduate students chose the banks to patronize. The survey concluded that for customers to become loyal, banks should emphasize that they can make the undergraduate students feel secure. The key focus of any marketing campaign should be on making customers feel secure, particularly emphasizing the bank's stability. Banks should also try to build good brand image, as many of the customers prefer to have accounts in prominent banks where security arrangements are good so they can be assured of the safety of their money (Sharma and Rao, 2010).

Rehman and Ahmed (2008) reveal that convenience is one of the most important variables influencing customer choices. Other factors such as customer services, online banking facilities and overall electronic services (ATM) which gives them quick and convenient access to the bank services (Mokhlis, 2009), without visiting the banking hall at any time (Okeke, 2008), followed suit. Sharma and Rao (2010) studying banking selection criteria employed by MBA students in India included convenience as an important determinant. Factors such as parking facility, free delivery of demand, phone banking, and free home cash delivery, suggest that customers want convenience in banking.

Almossawi (2001) points out that proximity and service quality are important factors in commercial bank selection by customers. This suggests that university students will prefer to bank with commercial banks with offices or ATM facilities that are close to their campuses. Almossawi (2001) adds that even though there are schemes which enable ATM cardholders to use ATMs of any bank, they still need to visit the bank when necessary for some services which cannot be done through ATMs. According to Mokhlis (2009) service provision came second in terms of relative importance considered by female customers when selecting their banks. The importance of service provision is further evidenced by the study conducted by Gerrard and Cunningham (2001) on how undergraduate students choose the banks in Singapore.

Cicic, Brkic and Agric (2004) point out that cost is another important determinant of commercial bank selection especially for university students. University students are non-income earners, and their primary objective is to minimize costs that are associated with financial transactions. This means that student- customers will prefer service charges as the most driving factor. According to Cicic, et al. (2004) the most important bank selection determinant for the Bosnia and Herzegovina students falls within financial benefits including, first of all, service charges taking into consideration the low level of living standard and low average income in Bosnia and Herzegovina. On the contrary Cicic, et al. (2004) point out that factors like close proximity to home and work, and price of the product are perceived to be the least important criteria for banks selec-

Copyright (C) 2013, Asian Business Consortium | ABR tion.

According to Almossawi (2001) and Lenka, Suar and Mohopatra (2009) another important determinant of commercial bank selection is technology. Managers realize that young people enjoy dealing with advanced technical devices such as ATMs, in spite of negative factors regarding their usage (Ogbuji, Izogo and Onuoha, 2011). This indicates that in their bank selection, the new generation of customers tends to put more emphasis on the factors which give them quick and convenient access to the bank services, rather than factors related to the hospitality, condition of the bank premises, and location of the bank. Almossawi (2001) notes that the vast majority of young people prefer to use ATMs, not only for their speed and convenience, but also for the ability to demonstrate their techsavvy instincts.

In corroboration, Gerrard and Cunningham (2001), and Kaynak and Harcar (2005) contend that electronic services are of relative importance. Even though they were not available for that long, the current well-educated generation has been exposed to modern technology in their higher education which will increase their drive to patronize banks that are regarded as technology leaders.

Cicic, et al. (2004), and Maddern, Maull and Smart (2007), researching on the dissatisfiers, pointed out that incompetence and lack of courtesy of banks' personnel are major reasons customers exit the banks. The studies revealed that customers highly regard knowledgeable and competent personnel coupled with friendly and courteous values, to be the most important criteria in patronizing banks. Cicic, et al. (2004) argued that contrary to the studies conducted in developed countries which found that the most important bank selection determinants are related to technology and automated teller machines, friendliness of staff lays a major role in the bank selection process in Bosnia and Herzegovina. A study conducted by Almossawi (2001) to examine the bank selection criteria employed by college students in Bahrain revealed that bank's reputation is one of the key factors. This was supported by Iruka and Igwe (2010) who stated that a positive (brand) image also leads to consumer loyalty, positive beliefs about brand value, and a willingness to search for the bank. For today's young people, brand name is one of the major factors that determine their decisions for goods and services. Referrals are also an important factor in selecting a bank for both male and female customers (Almossawi, 2001) despite the fact that young people prefer to act independently. In contrast, Gerrard and Cunningham (2001) find that third party influences are of little importance in commercial bank selection by customers.

\section{Research Methodology}

The study used the quantitative research methodology. The study unit for the research focused on the students of 72 | P a g e 
Michael Okpara University of Agriculture, Umudike, being the only federal university in Abia State. Consequently, the student enrolment is diverse, covering different ethnic hues in Nigeria.

These students are faced with a diverse choice of commercial banks, situated in the campus - Umudike, and in the nearby state capital - Umuahia. 250 respondents were studied from the ten different colleges of the university. This size is based on convenience. The study used the non-probability sampling method: the sample elements were drawn from different final year classrooms, based on the researchers' judgment that their length of studentship should make them better informed on the circumstances of university students' banking. This sampling technique ensured better response rate, corroborating Ezejelue, Ogwo and Nkamnebe (2008). The researchers distributed 250 copies of the questionnaire across the 10 Colleges of the university, in the classrooms.

Further, the study used the survey method of primary data collection. Cooper and Schindler (2006) noted that the broad area of survey research encompasses any measurement procedures that involved asking questions. In survey research, the researchers selected sample respondents from a population and administered a copy of the questionnaire to them.

The used questionnaire was divided into two sections. While Section A focused on the demographic profile and banking history of respondents, Section B asked the respondents to agree or disagree with questions related to the determinants of choice of commercial banks, using a five-point Likert scale ranging from "Strongly Disagree" to "Strongly Agree". The questions were adapted from a stream of previous studies conducted by Almossawi (2001), Mokhlis (2009), and Cleopas and Olawale (2011). This resulted in the development of a 40-item questionnaire crucial to bank selection. Close-ended questions were limited to Section A. The questionnaire was pretested for validity in a pilot study of 30 students of the University. The process of pre-testing helped the researchers to identify areas where the questionnaire needed corrections. The Cronbach's alpha was used as the measure of reliability. The alpha coefficient ranges in value from 0 to 1 .The higher the score, the more reliable the general scale is. However, Cooper and Schindler (2003) noted that a score of 0.7 is the acceptable reliability coefficient.

Apart from the traditional analytical tools such as tables and percentages, data were also analysed using descriptive statistics and principal component analysis (PCA) in SPSS (16.0). PCA, according to Ezejelue, et al. (2008), is a multivariate technique that simultaneously analyses more than two (indeed tens and hundreds of) variables in order to identify and describe some underlying dimensions which may not be obvious and indeed, may not be measureable in a set of data, yet could be critical in explaining the behaviour or character of such data. This study used Varimax orthogonal rotation method developed by Kaiser in 1958. Principal components with Eigen values greater than one are usually retained. Items with factor loading lower than 0.300 were removed as suggested by Leech, Barrett and Morgan (2005).

\section{AnALysis}

\subsection{Return Pattern of Questionnaire}

250 copies of the questionnaire were distributed to the respondents, out of which $186(74.4 \%)$ were correctly completed, returned and used. $29(11.6 \%)$ were not returned, while $35(14.0 \%)$ were completed and returned, but were not used due to certain inconsistencies. Details are as shown in Table 4.1.

Table 4.1: Return of Questionnaire

\begin{tabular}{|l|l|l|}
\hline Patterns & Number & Percentage \\
\hline Not returned & 29 & 11.6 \\
\hline Returned but not used & 35 & 14.0 \\
\hline Returned and used & 186 & 74.4 \\
\hline Total & 250 & 100 \\
\hline
\end{tabular}

\subsection{Demographic Profile of Respondents}

Gender was almost evenly split in the proportions of $51.1 \%$ and $48.9 \%$ for males and females, respectively. $21.5 \%$ of the respondents were below 21 years, $45.2 \%$ were $21-25$ years, $14.0 \%$ were $26-30$ years, $10.2 \% 31-35$ years and $9.1 \%$ above 35 years. $79.6 \%$ were undergraduate students and $20.4 \%$ postgraduate students. The respondents, as shown in Table 4.2, cut across all the 10 Colleges of the University, with Agric-Business (30\%) and Financial Management (16.1\%) topping the Table. Out of the 186 respondents that returned the questionnaires, $96.8 \%$ have bank accounts. $92.2 \%$ of them opened their bank accounts when they enrolled as students of Michael Okpara University of Agriculture, Umudike. The remaining 7.8\% already held bank accounts before enrolment at the university. First bank is the most patronized with the proportion of $33.3 \%$, followed by Zenith Bank, GTB and UBA with the share of $18.9 \%, 17.8 \%$ and $12.8 \%$ respectively, leaving the remaining $17.2 \%$ for the rest of other banks. Table 4.2 shows the details.

Table 4.2: Demographic Profile of Respondents

\begin{tabular}{|l|c|c|c|c|c|c|}
\hline Items & $\begin{array}{l}\text { Frequ } \\
\text { ency }\end{array}$ & $\%$ & Items & \multicolumn{2}{|l|}{$\begin{array}{l}\text { Frequ } \\
\text { ency }\end{array}$} & $\%$ \\
\hline Gender & \multicolumn{7}{|c|}{ Owned Bank Account } \\
\hline Male & 95 & 51.1 & Yes & 180 & 96.8 \\
\hline Female & 91 & 48.9 & No & 6 & 3.2 \\
\hline Total & 186 & 100.0 & Total & 186 & 100.0 \\
\hline Age & \multicolumn{5}{|c|}{ When Account was Opened } \\
\hline Below 21 & 40 & 21.5 & $\begin{array}{c}\text { Before } \\
\text { enrolment }\end{array}$ & 14 & 7.8 \\
\hline $21-25$ & 84 & 45.2 & $\begin{array}{c}\text { After } \\
\text { enrolment }\end{array}$ & 166 & 92.2 \\
\hline $26-30$ & 26 & 14.0 & Total & 180 & 100.0 \\
\hline
\end{tabular}

Copyright $($ 2013, Asian Business Consortium | ABR 


\begin{tabular}{|c|c|c|c|c|c|}
\hline $31-35$ & 19 & 10.2 & $\begin{array}{c}\text { Respondents' } \\
\text { Banks }\end{array}$ & & \\
\hline Above 35 & 17 & 9.1 & First Bank & 60 & 33.3 \\
\hline \begin{tabular}{|l|} 
Total \\
\end{tabular} & 186 & 100.0 & Zenith Bank & 34 & 18.9 \\
\hline $\begin{array}{l}\text { Level of } \\
\text { Education }\end{array}$ & & & GTB & 32 & 17.8 \\
\hline $\begin{array}{l}\text { Underg } \\
\text { raduate }\end{array}$ & 162 & 87.1 & UBA & 23 & 12.8 \\
\hline \multirow{2}{*}{$\begin{array}{l}\text { Postgra } \\
\text { duate }\end{array}$} & 24 & 12.9 & Others & 31 & 17.2 \\
\hline & 186 & 100.0 & Total & 180 & 100.0 \\
\hline \multicolumn{3}{|l|}{ *College } & & & \\
\hline CNAS & 17 & 9.1 & & & \\
\hline CAERSE & 21 & 11.3 & & & \\
\hline CNREM & 19 & 10.2 & & & \\
\hline CEET & 17 & 9.1 & & & \\
\hline CASAP & 15 & 8.1 & & & \\
\hline CCSS & 20 & 10.8 & & & \\
\hline CAFST & 18 & 9.7 & & & \\
\hline CABFM & 30 & 16.1 & & & \\
\hline CVM & 14 & 7.5 & & & \\
\hline CASE & 15 & 8.1 & & & \\
\hline Total & 186 & 100.0 & & & \\
\hline
\end{tabular}

Source: Survey Data, 2012.

* The acronym for each of the colleges.

\subsection{Determinants of Choice of Commercial BanKS}

\subsubsection{The Descriptive Statistics}

The determining factors for the choice of commercial banks are as shown in Table 4.3.

The table shows that the most important factors for university students in choosing commercial banks have highest mean values. Therefore, ease of opening an account, availability of ATM service in several locations, availability of 24-hour ATM service, and provision of fast and efficient services, are crucial, having mean values of 4.95 , $4.93,4.93$, and 4.91 respectively. The factors with the lowest mean values are free gifts for customers (2.81), availability of public transport (2.94), financial counseling services (2.95), and career development programme (3.01). These factors are less important in the choice of commercial banks. Other details are contained in Table 4.3.

Table 4.3: Determinants of the Choice of Commercial Banks by Students

\begin{tabular}{|l|l|l|l|}
\hline Ranking & \multicolumn{1}{|c|}{ Variable } & Mean & $\begin{array}{l}\text { Stan } \\
\text { dard } \\
\text { Error }\end{array}$ \\
\hline 1 & Easy of opening an account & 4.95 & 0.11 \\
\hline 2 & Availability of ATN in several locations & 4.93 & 0.27 \\
\hline 3 & Availability of ATM 24 hours & 4.93 & 0.19 \\
\hline 4 & Provision of fast and efficient service & 4.91 & 0.12 \\
\hline 5 & Convenient branch location & 4.81 & 0.11 \\
\hline 6 & Appropriate range of service offered & 4.81 & 0.14 \\
\hline 7 & Branch opening hours & 4.69 & 0.12 \\
\hline 8 & Sponsor uses the same bank & 4.69 & 0.11 \\
\hline 9 & Pleasant bank atmosphere & 4.65 & 0.12 \\
\hline 10 & Staff courtesy & 4.63 & 0.11 \\
\hline 11 & Proximity to the university & 4.59 & 0.18 \\
\hline 12 & Reputation of the bank & 4.52 & 0.11 \\
\hline 13 & Professionalism of bank staff & 4.49 & 0.27 \\
\hline 14 & Adequate number of tellers & 4.49 & 0.14 \\
\hline
\end{tabular}

\begin{tabular}{|c|c|c|c|}
\hline 15 & Attractiveness of bank building & 4.43 & 0.13 \\
\hline 16 & Influence of parents & 4.43 & 0.14 \\
\hline 17 & Cell phone banking facilities & 4.27 & 0.13 \\
\hline 18 & Regular Bank statement & 4.12 & 0.14 \\
\hline 19 & Several branches & 3.99 & 0.14 \\
\hline 20 & Proximity to home & 3.98 & 0.12 \\
\hline 21 & Appearance and attire of staff & 3.93 & 0.15 \\
\hline 22 & The school use the same bank & 3.89 & 0.14 \\
\hline 23 & Interior décor of building & 3.81 & 0.12 \\
\hline 24 & Low service charges & 3.81 & 0.13 \\
\hline 25 & Recommendations of friends & 3.76 & 0.12 \\
\hline 26 & Parking space & 3.75 & 0.10 \\
\hline 27 & Recommendations of relatives & 3.75 & 0.13 \\
\hline 28 & Influential marketing campaign & 3.74 & 0.22 \\
\hline 29 & Internet banking facility & 3.69 & 0.14 \\
\hline 30 & Foreign exchange & 3.69 & 0.41 \\
\hline 31 & Financial stability of the bank & 3.69 & 0.14 \\
\hline 32 & Influence of lecturers & 3.53 & 0.13 \\
\hline 33 & Brand name/slogan & 3.49 & 0.13 \\
\hline 34 & Confidentiality & 3.43 & 0.15 \\
\hline 35 & Grants to students & 3.33 & 0.26 \\
\hline 36 & Higher returns (interest) on savings & 3.15 & 0.13 \\
\hline 37 & Career development program & 3.01 & 0.12 \\
\hline 38 & Financial counseling services & 2.95 & 0.12 \\
\hline 39 & Available public transport nearby & 2.94 & 0.21 \\
\hline 40 & Free gifts for customers & 2.81 & 0.10 \\
\hline
\end{tabular}

\subsubsection{The Principal Component Analysis}

In order to reduce the choice criteria to a manageable level, the principal component analysis (factor analysis), as suggested by Ezejelue, et al. (2008) and Ibekwe (2011), was used. The choice criteria were reduced to six factors, which were confirmed by the sums of squared loading after Varimax rotation. According to the rules of factor analysis, only factors that have Eigen values greater than one should be retained. The six factors for choice of commercial banks are presented in Table 4.4 in the order of importance as indicated by their contribution to the percentage of total variance. Factor one was labeled as service. The Eigen value for the factor is 33.68. The factor includes fourteen items (see Table 4.4). Cronbach's alpha for the factor yielded a value of 0.762 indicating the reliability of the factor. Factor two was labeled proximity with an Eigen value of 25.21. The factor includes two items. Cronbach's alpha for the factor yielded a value of 0.821 indicating its reliability. Factor three was labeled attractiveness, with the Eigen value of 8.76. The factor consists of five items. Cronbach's alpha for the factor yielded a value of 0.795 indicating its reliability. Factor four on recommendations has the Eigen value of 4.32. The factor consists of six items. Cronbach's alpha for the factor yielded a value of 0.844 indicating the reliability of the factor. The fifth factor was labeled as marketing. Its Eigen value is 3.64, containing six items. Cronbach's alpha for the factor yielded a value of 0.795 , indicating reliability. Factor six was price, with an Eigen value of 2.71. It consists of four items, with a Cronbach's alpha of 0.751, indicating the reliability of the factor. Forty questions (items) were rotated to find their factor loading. From this number, thirtyseven items with factor loading above 0.3 were retained. 
Three items which are free gifts to students, financial counseling and availability of public transport had factor loadings lower than 0.3 and were removed as suggested by Leech, et al. (2005). Details are as shown in Table 4.4. Table 4.4: Rotated Factor Loading and Cronbach's Alpha

\begin{tabular}{|l|c|c|c|c|c|c|}
\hline & $\mathbf{1}$ & $\mathbf{2}$ & $\mathbf{3}$ & $\mathbf{4}$ & $\mathbf{5}$ & $\mathbf{6}$ \\
\hline Easy of opening an account & 0.837 & & & & & \\
\hline Availability of ATM in & 0.783 & & & & & \\
several locations & & & & & & \\
Availability of ATM 24 hours & 0.759 & & & & & \\
Convenient Branch location & 0.546 & & & & & \\
Appropriate range of & 0.534 & & & & & \\
service offered & & & & & & \\
Provision of fast and & 0.533 & & & & & \\
efficient service & & & & & & \\
Branch opening hours & 0.533 & & & & & \\
Staff courtesy & 0.505 & & & & & \\
Professionalism of bank staff & 0.491 & & & & & \\
Adequate number of tellers & 0.458 & & & & & \\
Cell phone banking facilities & 0.447 & & & & & \\
Regular Bank statement & 0.431 & & & & & \\
Internet banking facility & 0.421 & & & & & \\
Foreign exchange & 0.414 & & & & \\
\hline Proximity to the university & & 0.844 & & & & \\
\hline Proximity to home & & 0.752 & & & & \\
Pleasant bank atmosphere & & & 0.765 & & & \\
Attractiveness of bank building & & & 0.687 & & & \\
Appearance and attire of staff & & & 0.567 & & & \\
Interior décor of building & & & 0.434 & & & \\
Parking space & & & 0.301 & & & \\
\hline Sponsor uses the same bank & & & & 0.734 & & \\
\hline Influence of parents & & & & 0.606 & & \\
The school use the same bank & & & & 0.594 & & \\
Recommendations of friends & & & & 0.541 & & \\
Recommendation of relatives & & & & 0.427 & & \\
Influence of lecturers & & & & 0.421 & & \\
\hline Reputation of the bank & & & & & 0.897 & \\
\hline Several branches & & & & & 0.727 & \\
Influential marketing campaign & & & & & 0.613 & \\
Brand name/slogan & & & & & 0.563 & \\
Grants to students & & & & & 0.494 & \\
Career development program & & & & & 0.444 & \\
\hline Low service charges & & & & & & 0.817 \\
\hline Financial stability of the bank & & & & & & 0.761 \\
Confidentiality & & & & & 0.538 \\
Higher returns (interest) on & & & & & & 0.432 \\
savings & & & & \\
\hline Eigen values & & & & \\
\hline Cronbach's alpha & & & & \\
\hline
\end{tabular}

(Items with factors loading less than 0.300 were omitted)

\subsubsection{Mean Factor Scores}

Table 4.5 shows that the most important determinant of the choice of commercial banks by university students is services with a mean score of 4.53 on a five-point Likert scale. This is followed by proximity with a mean score of 4.29. Price though significant has the lowest mean score of 3.52 .

Table 4.5: Mean Factor Scores

\begin{tabular}{|l|l|}
\hline Factor & Mean \\
\hline Services & 4.53 \\
\hline Proximity & 4.29 \\
\hline Attractiveness & 4.11 \\
\hline Recommendations & 4.01 \\
\hline Marketing & 3.68 \\
\hline Price & 3.52 \\
\hline
\end{tabular}

Copyright $(C 2013$, Asian Business Consortium | ABR

\section{FINDINGS AND CONCLUSION}

\subsection{Discussion OF Findings}

Based on the data analysis, the following findings were made:

1. Key bank services attributes by students range from account-opening convenience, effective ATM, staff courtesy, to phone services. Given the dynamics of these respondents - studious, tech-savvy - this finding is instructive, and agrees with the findings of $\mathrm{Ci}$ cic, et al (2004), and Maddern, et al (2007). Technology-driven services are important.

2. Proximity to banks, both at home and at school, is a vital bank choice determinant among students. This implies that banks would do well to have a significant branch network, so that their services can be accessed during on or off school periods.

3. Corporate looks is found important in bank choice. This consists of the building, interiors, staff dress sense, etc. Cleopas and Olawale (2012) earlier noted that these subtle attributes instill confidence and impress young minds more than it does the elders.

4. Contrary to existing literature (Cicic, et al, 2004), our respondents consider price-related strategies, least important. These include interest rates and service charge. This is interesting, given that the respondents are mostly dependants who ought to be deal-prone.

\subsection{CONCLUSION}

The study makes important contribution to the body of literature on the determinants of the choice of commercial banks by university students from the Nigerian perspective, where empirical studies are virtually non-existent. The theoretical foundation of the study is the theory of constraints. Nigerian banks are faced with the constraint of competitive pressure and a rapidly changing business environment. Empirically the study identified the important determinants of commercial bank selection by student-customers to include speed, courtesy, convenience. Bank managers who have branches on university campuses should be mindful of these service treasureattributes, in their bid to create and deliver superior value to their student clientele. These petty student accounts had been proved to be blue-chip accounts in later years! Specifically, the following recommendations are consequently proffered:

1. Commercial banks should make it easier for university students to open accounts by having regular account opening days or allowing accounts to be opened online. This will reduce or eliminate the need for university students to go to bank branches to open accounts.

2. Functional ATMs should be located by banks at strategic points within the university campuses to allow for quick transactions.

3. There is the need for Nigerian banks to speed up the 
process of opening branches in university towns. This will also improve proximity which is another significant determinant of commercial bank selection.

4. Bank management should ensure that their branches and personnel courteous in manner, and pleasant in outlook.

5. Banks should regularly conduct marketing research to monitor the change in student-customer patterns and needs. The fact that university students represent the future working and entrepreneurial classes means that proper management of their today needs will guarantee a lucrative long-term relationships with their banks.

\section{REFERENCES}

Almossawi, M. (2001), "Bank Selection Criteria Employed by College Students in Bahrain: An Empirical Analysis," International Journal of Bank Marketing, 19 (3): 115-125.

Anyanwu, A. (2000), Research Methodology in Business and Social Sciences, Owerri: Canun. Publishers Nig. Ltd.

Arasli, H., Katircioglu, S., and Smadi, S.M. (2005), "Service Quality in Businessday (2012), "Banking Landscape", 4(7), July.

Cicic, M, Brkie, N., and Agic, E. (2004), "Bank Selection Criteria Employed by Students in South-eastern European Country: An Empirical Analysis of Potential Market Segments Preferences", International Journal of Bank Marketing, 27 (2): 1-18.

Cleopas, C and Olawale, F. (2011), "Factors Influencing the Choice of Commercial Banks by University Students in South Africa" International Journal of Business and Management, 6(6): 66-76.

Commercial Banking: Empirical Evidence from Turkish- and GreekSpeaking Areas of Cyprus", International Journal of Bank Marketing, 23(7):508-526.

Cooper, D. and Schindler, P. (2006), Marketing Research, $3^{\text {rd }}$ ed., New York: McGraw. Hill/Irwin.

Ezejelue, A.C., Ogwo, E. O. and Nkamnebe, A.D. (2008), Basic Principles in Managing Research Projects, $2^{\text {nd }}$ ed, Aba: Afritowers.

Gerrard, P. and Cunningham, J.B. (2001),"Bank Service Quality: A comparison between a Publicly Quoted Bank and a Government Bank in Singapore", Journal of Financial Services Marketing, 6(1): 50-66.

Haque, A., Osman, J. and Ismail, A. (2009), "Factors Influencing Selection of Islamic Banking: A Study of Malaysian Customer Preferences", American Journal of Applied Sciences, 6(5):

Hinson, R., Dasah, J. and Owusu-Frimpong, N. (2009), “Undergraduate First Time Bank Customers' Perception of Service Quality in Ghana", [Online] Available: http://www. Business.aau.dk/ivo/publications/working/wp49 (July 8, 2011).

Ibekwe, C.F. (2011), Statistics of Marketing Research, Owerri: Uzopietro Publishers.

Iruka, C.H. and Igwe, S.R. (2010), Brand Management: Concepts and Strategies, Port Harcourt: Orji Publishing House.

Karatepea, O.M., Yavas, U. and Babakus, E. (2005), "Measuring Service Quality of Banks: Scale Development and Validation", Journal of Retailing and Consumer Services, 12 91): 373-383.

Kaynak, E., and Harcar, E. (2005), “American Consumers' Attitudes towards Commercial Banks: A Comparison of Local and National Bank Customers by Use

Lee, J. and Marlowe, J. (2003), "How Consumers Choose a Financial Institution: Decision-making Criteria and Heuristics", International Journal of Bank Marketing, 21 (2: 53-71.
Leech, N.L., Barrett, K.C. and Morgan, G.A. (2008), SPSS for Intermediate Statistics, Use and Interpretation, $2^{\text {nd }}$ ed., New Jersey: Lawrence Erlbaum Associates Inc.

Lenka, U., Suar, D. and Mohapatra, P.K.J. (2009), “Commercial Banks Service Quality, Customer Satisfaction, and Customer Loyalty in India", Journal of Entrepreneurship, 18 (1): 47-64.

Mabin, V. and Balderstone, S. (2003), "The Performance of the Theory of Constraints Methodology: Analysis and Discussion of Successful TOC Applications", International Journal of Operations and Production Management, 23 (6): 568-595.

Maddern, H., Mautt, R, and Smart, A. (2007), "Managing Service Quality in Banks: Customers' Gender Effects", Internationals Journal of Operational and Production Management, 27(9):998-1019.

Mokhlis, S. (2009), "Determinants of Choice Criteria in Malaysia's Retail Banking: An Analysis of Gender-based Choice Decisions", European Journal of Economics, Finance and Administrative Sciences, 1(2): 1450-1467.

Mokhlis, S., Mat, N.H.N. and Salleh, H.S. (2008), "Commercial Bank Selection: Comparison between Single and Multiple Banks Users in Malaysia", International Journal of Economics and Finance, 1(2): 263-273.

NUC (2013), A Portal of the National Universities Commission, accessed on line: www.nuc.edu.ng/pages/universities.asp. on 4 March, 2013.

of Geo-demographic Segmentation", International Journal of Bank Marketing, 23(1): 73-89.

Ogbuji, C.N. (2009), "Impact of Branding on Consumer Choice for Regulated Bottled Water in South-east, Nigeria", Ph.D Thesis submitted to the Department of Marketing, Abia State University, Uturu, Nigeria.

Ogbuji, C.N., Izogo, E.E., and Onuoha, A. O. (2012), "An X-Ray of the Level of Electronic Purse Usage in Nigeria", African Research Review, 5(6): 199-212.

Okeke, C.I. (2009), "Electronic Bank in Nigeria: Emerging Marketing Issues and Challenges", Ph.D. Thesis submitted to the Department of Marketing, Abia State University, Uturu, Nigeria.

Okpara, G.S. (2002), Contemporary Marketing: Topical and Tropicalized, Enugu: John Jacob's classic Publishers Ltd.

Rehman, H.U.R and Ahmed, S. (2008), "An Empirical Analysis of the Determinants of Bank Selection in Pakistan: A Customer View", [Online] Available:http:/ /www.emeraldimsight.com/journals.htm?issn $=02653 \&$ volume $=19 \&$ issue $=3 \&$ articleid $=855031 \&$ show $(\mathrm{Au}-$ gust 23, 2011).

Roberts-Lombard, M. (2002), Marking Research: A South African Perspective, $3^{\text {rd }}$ ed., Cape Town: Oxford University Press.

Sharma, R.K. and Rao, S.A. (2010), "Bank Selection Criteria Employed by MBA Students in Delhi: An Empirical Analysis", Journal of Business Studies, 1(2): 56-69.

Ta, H. P. and Har, K.Y. (2000), "A Study of Bank Selection Decisions in Singapore Using the Analytical Hierarchy Process", International Journal of Bank Marketing, 18(1): 170-180.

$$
--0
$$

